\title{
A MANGANESE SUPEROXIDE DISMUTASE (SOD2) GENE POLYMORPHISM IN INSULIN-DEPENDENT DIA- BETES MELLITUS
}

\author{
FLEMMING POCIOT, TOVE LORENZEN AND JØRN NERUP \\ Steno Diabetes Center, DK-2820 Gentofte, Denmark.
}

\begin{abstract}
SUMMARY
Interleukin 1 (IL-1) is selectively cytotoxic to the insulin producing beta cell of pancreatic islets. This effect may be due to IL-1 induced generation of reactive oxygen species and nitric oxide. Since beta cells contain low amounts of the superoxide radical scavenger enzyme manganese superoxide dismutase (MnSOD), this may leave beta cells more susceptible to IL- 1 than other cell types. Genetic variation in the MnSOD locus could reflect differences in scavenger potential. We, therefore, studied possible restriction fragment length polymorphisms (RFLPs) of this locus in patients with insulin-dependent diabetes mellitus (IDDM) $(n=154)$ and control individuals $(\mathrm{n}=178)$. TaqI revealed a double diallelic RFLP in patients as well as in controls. No overall difference in allelic or genotype frequencies were observed between IDDM patients and control individuals ( $\mathrm{p}=0.11$ ) and no significant association of any particular RFLP pattern with IDDM was found. Structurally polymorphic MnSOD protein variants with altered activities have been reported. If genetic variation results in MnSOD variants with reduced activities, the MnSOD locus may still be a candidate gene for IDDM susceptibility. Whether the RFLPs reported in this study reflects differences in gene expression level, protein level and/or specific activity of the protein is yet to be studied.
\end{abstract}

KEYWORDS MnSOD RFLP Free oxygen radicals NO Susceptibility genes

\section{INTRODUCTION}

The cytokine interleukin $1 \beta$ (IL-1), mainly produced by the monocyte (Mo)/macrophage (Mø) cell lineage, is selectively cytotoxic to beta-cells in isolated pancreatic islets (Mandrup Poulsen et al. 1986, Bendtzen et al. 1986, Sandler et al. 1987). The effects of IL-1 include decreased insulin biosynthesis and release, decreased glucose oxidation, oxygen uptake, protein synthesis and islet content of insulin and DNA (Sandler et al. 1987, Sandler et al. 1989). Since the first cells to appear in the insulitis process are Mo/ Mø (Vorbij et al. 1989, Hanenberg et al. 1989, O'Reilly et al. 1991), IL-1 may be responsible for the initial beta-cell damage eventually resulting in insulin-dependent diabetes mellitus (IDDM) (Nerup et al. 1988). The detailed mechanisms behind the cytotoxic effect of IL-1 to beta-cells are not fully clarified.

The parameter which is first influenced by IL-1, is the cytosolic free sodium concentration $\left(\mathrm{fNa}^{+} \mathrm{i}\right.$ ). In rat islets, $\mathrm{fNa}^{+} \mathrm{i}$ increases within minutes of IL- 1 exposure, due

Correspondence to: Flemming Pociot, M.D., Steno Diabetes Center, Niels Steensensvej 2, DK2820 Gentofte, Denmark. 
to an activation of the $\mathrm{Na}^{+} / \mathrm{H}^{+}$exchange over the plasma membrane (Helqvist et al. 1990). IL-1 induces oxygen-derived free radicals (OFR) in other cells (Klempner et al. 1979, Matsubara et al. 1986) and nitric oxide (NO) in islets (Southern et al. 1990, Welsh et al. 1991, Andersen et al. 1993), and it has been shown that an activation of the $\mathrm{Na}^{+} /$ $\mathrm{H}^{+}$increases OFR production in neutrophil granulocytes (Simchowitz et al., 1985). The beta cell cytotoxic agent alloxan induces production of OFR (Malaisse et al 1982). Beta cells have been suggested to be particularly sensitive to the toxic effect of OFR due to a limited repertoire of $\mathrm{O}_{2}{ }^{-}$scavengers like the enzyme manganese superoxide dismutase (MnSOD). The role of SODs is to remove damaging OFR from the cell by reducing them to hydrogen peroxide, which in term is removed by other enzymes. IL- 1 is a major inducer of MnSOD (Wong et al. 1988, Masuda et al. 1988) and also increases the transcription (Cuartero et al. 1992) and the activity of the enzyme in rat pancreatic islets (Borg et al. 1992). Very recent data have shown IL-1 to induce nitric oxide synthase (iNOS) in a number of cell types (Busse and Mülsch 1990, Stadler et al. 1991, Nussler et al. 1992) including islets (Karlsen et al. 1993) resulting in higher intracellular levels of NO. Data suggest also that part of the NO cytotoxicity may derive from its combining with superoxide, leading to the formation of peroxynitrite anion, which decomposes when protonated into the toxic hydroxyl radical (Beckman et al. 1990). Thus, if IL-1 induces formation of OFR and NO in beta-cells, the beta-cell specific cytotoxicity may reflect insufficient capability of these cells to produce protective proteins, e.g. MnSOD, that are normally constitutively expressed or inducible in other cell types. Furthermore, peripheral blood mononuclear cells (PBMC) from diabetic individuals showed decreased mitochondrial SOD-activity, though the total amount of MnSOD was not reduced (Nath et al. 1984). We hypothesize that genetic variation(s) at the MnSOD locus reflect interindividual differences in scavenger potential, which might render some individuals more susceptible to IL-1 mediated beta cell destruction and IDDM.

In the present study we, therefore, searched for restriction fragment length polymorphisms (RFLPs) of the human MnSOD gene and subsequently evaluated the allele and genotype distribution in IDDM patients and healthy control individuals.

\section{MATERIALS AND METHODS}

\section{Subjects}

A panel of 10 IDDM patients and 10 control individuals were screened for RFLPs using different restriction enzymes. For further analysis an independent sample of 154 unrelated randomly selected IDDM patients and 178 healthy, unrelated randomly selected control individuals were studied. In addition, 4 two-generation families (22 individuals) and 1 three-generation family ( 8 individuals) were typed in order to determine segregation of the different MnSOD alleles. All individuals studied were of Caucasoid origin.

The study was approved by the Ethics Committee of the County of Copenhagen.

\section{Restriction fragment length polymorphism (RFLP) studies}

DNA was extracted from peripheral blood mononuclear cells by standard procedures and digested with the following restriction enzymes: AccI, AvaI, AvaII, BamHI, BclI, BglII, EcoRI, HindIII, HinfI, KpnI, MspI, NcoI, PstI, PvuII, RsaI, SacI, SspI, StuI, TaqI, or XbaI. After electrophoresis of $10 \mu \mathrm{g}$ DNA in a $0.8 \%$ agarose gel and blotting to a nylon 
filter (GeneScreen Plus), DNA was hybridized with a human cDNA probe. The probe was an 588 bp NdeI-SalI fragment isolated from pcMnHSOD1lacI ${ }^{2}$. The NdeI-SalI fragment was derived from the MnSOD cDNA and encodes the mature protein but not the mitochondrial targeting sequence. The probe was kindly provided by Dr. R. Hallewell, Chiron Corporation, Emeryville, CA.

\section{Statistical analysis}

Genotype- and allele frequencies were compared using Fisher's exact test or chisquare with Yates correction where appropriate. Five per cent (two-sided) was chosen as level of significance unless otherwise stated. Linkage was estimated according to Mattiuz et al (Mattiuz et al.1970).

\section{RESULTS}

Only the restriction enzyme TaqI revealed a polymorphic pattern. The MnSOD cDNA probe used in this study identified 7 fragments, termed 1 to 7 , after digestion with TaqI, where fragment 1 had the lowest molecular weight (MW) and fragment 7 the highest MW (Fig.1). Three of the fragments were constant, i.e found in all individuals, with sizes of $3.8,3.2$, and $1.4 \mathrm{~kb}$, and two diallelic polymorphisms consisted of fragments of $2.3 \mathrm{~kb} /$ $2.0 \mathrm{~kb}$ (RFLP A) and $1.5 \mathrm{~kb} / 1.2 \mathrm{~kb}$ (RFLP B), respectively, (Fig. 1).

Table 1 shows the frequencies of the 4 polymorphic alleles in 154 randomly selected IDDM patients and 178 healthy individuals. No differences between IDDM patients and control individuals were observed. No deviation from Hardy-Weinberg equilibrium was observed.

Table 2 shows the frequencies of the MnSOD TaqI RFLP genotypes in patients and control subjects. Only 6 of 9 theoretical genotypes were found in IDDM patients as well as in control individuals.

No significant difference in overall genotype frequency between patients and controls was observed $(p=0.11)$. The most obvious differences were in frequencies of the homozygous genotypes, where homozygosity for fragment 1 and 5 was more frequent in diabetic individuals. However, non of these differences were significantly when corrected for number of comparisons. The difference in frequencies were reflected by significantly stronger linkage of fragment 1 with fragment 4 in controls compared to patients ( $\mathrm{p}=0.0003$ and $\mathrm{p}=0.087$, respectively).

The family analysis demonstrated codominant segregation of the polymorphic fragments. In families where it was possible to define haplotypes derived from heterozygous individuals, allele 1 and 4 co-segregated and so did allele 3 and 5, reflecting the strong linkage of these alleles.

\section{DISCUSSION}

Only the restriction enzyme TaqI revealed a polymorphic pattern with a double diallelic RFLP. These RFLPs were originally reported by Xiang et al (Xiang et al. 1987), who studied small groups of healthy individuals of Caucasian and Chinese origin. In this larger study we used a probe which identified 3 constant fragments, including a $1.4 \mathrm{~kb}$ fragment not previously reported. The frequencies of the polymorphic alleles were close to that reported by Xiang et al (Xiang et al. 1987) for Caucasoids. 

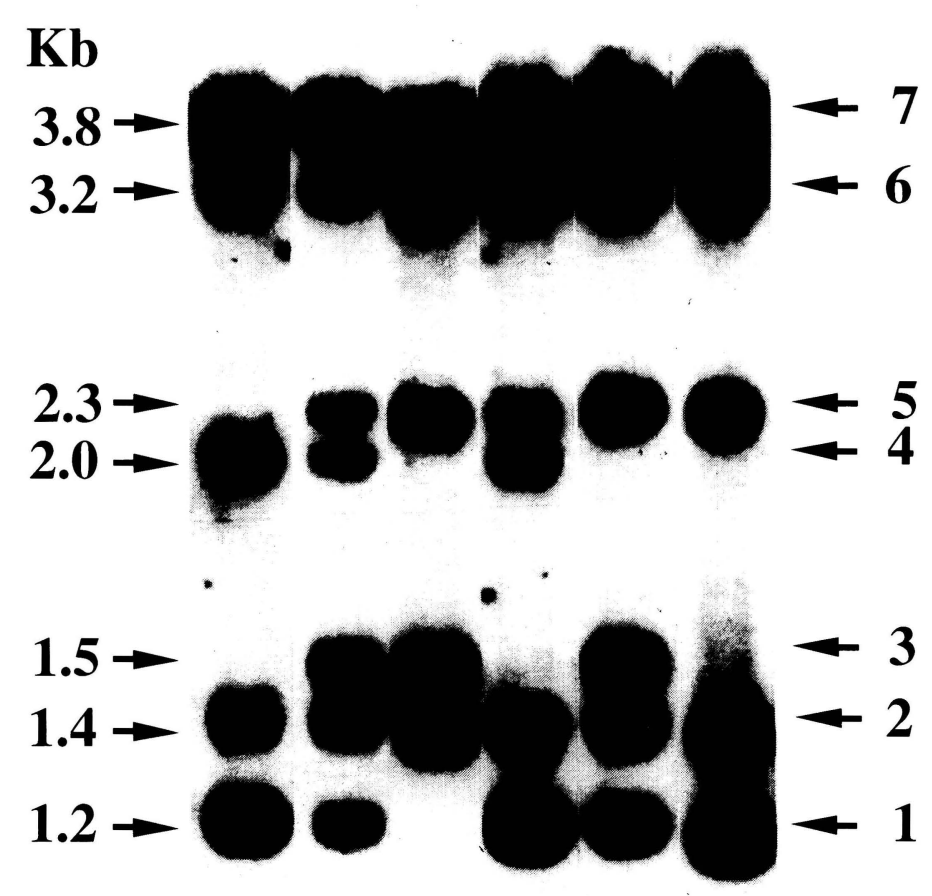

Figure 1. DNA from six healthy individuals digested with the restriction enzyme Taq1 and hybridized with a ${ }^{32}$ P-labelled MnSOD cDNA probe. Six different patterns were identified. Fragments are numbered after molecular size. Fragments 2, 6, and 7 were found in all tested individuals. Fragments 1 and 3 comprises one diallelic RFLP (B) and fragments 4 and 5 another, RFLP A.

Table 1. Allelic frequencies of polymorphic MnSOD TaqI alleles in IDDM patients and controls.

\begin{tabular}{c|cccc}
\hline & \multicolumn{2}{|c}{ RFLP B } & \multicolumn{2}{c}{ RFLP A } \\
\cline { 2 - 5 } Allele \# & $\mathbf{1}$ & $\mathbf{3}$ & $\mathbf{4}$ & $\mathbf{5}$ \\
\cline { 2 - 5 } IDDM ptt. $(\mathbf{n = 1 5 4 )}$ & 0,75 & 0,25 & 0,61 & 0,39 \\
& & & & \\
Controls (n=178) & 0,72 & 0,28 & 0,64 & 0,36 \\
\hline
\end{tabular}


Table 2. MnSOD TaqI genotype frequencies in random IDDM patients and control individuals.

\begin{tabular}{c|c|c|c|c|c|c|c|c|c}
\hline Fragment \# & $1,3,4,5$ & $1,3,4$ & $1,3,5$ & $1,4,5$ & 1,4 & 1,5 & 3,4 & $3,4,5$ & 3,5 \\
\hline $\begin{array}{c}\text { IDDM ptt } \\
(\mathbf{n = 1 5 4})\end{array}$ & 42 & 0 & 21 & 38 & 33 & 13 & 0 & 0 & 7 \\
$\begin{array}{c}\text { Controls } \\
(\mathbf{n = 1 7 8})\end{array}$ & 46 & 0 & 20 & 38 & 52 & 6 & 0 & 0 & 16 \\
\hline
\end{tabular}

In both IDDM patients and control individuals 6 of 9 theoretical genotypes were identified. Allele 4 and 5 comprise one diallelic RFLP (RFLP A), whereas allele 1 and 3 comprise another diallelic RFLP (RFLP B). Combinations with allele 3 and 4 on the same haplotype were not observed.

No fragment pattern occurring only in IDDM patients was observed. Unexpectedly, only 6 different genotypes were observed. The reason for this was that fragment 3 (RFLP B) always occurred with fragment 5 (RFLP A), and fragment 4 (RFLP A) with fragment 1 (RFLP B), indicating that if the TaqI-site identifying RFLP B was deleted so was the TaqI-site identifying RFLP A, and if the TaqI site identifying RFLP A was preserved so was the TaqI site identifying RFLP B. Since the two polymorphic TaqI-sites are separated by at least one constant TaqI-site, this observation suggests that nucleotide changes may occur simultaneously in different regions of the gene. In contrast, deletion of the TaqIsite identifying RFLP A was not necessarily associated with deletion of the other polymorphic TaqI-site. However, 26.5\% (88/332) of all tested individuals were heterozygous for both RFLPs, thus not allowing exact haplotype assignment of the polymorphic fragments. Since the genomic sequence of the human MnSOD has not been reported the exact position of the polymorphic TaqI-sites cannot be assigned.

No significant differences in allelic or overall genotype frequencies were observed between patients and controls. A difference in linkage of the alleles of the two RFLP's was found between controls and patients. The implication of this is not clear.

We have proposed IDDM to be a polygenic disease in which MHC class II specificities confer a major part of the genetic susceptibility, but other genes, including non-MHC genes, must be involved (Spielman et al. 1989, Pociot et al. 1990, Pociot et al. 1992, Pociot et al. 1993a). Though the present data do not support a role of the present MnSOD polymorphisms as genetic markers, recent preliminary data demonstrated a difference in the MnSOD allelic frequency between familial and sporadic IDDM cases ( $\mathrm{p}=0.06$, twotailed) (Pociot et al. 1993b). Furthermore, linkage studies in NOD backcross mice [(NOD/Uf x C57BL/6)F1 x NOD/Uf] showed that the MnSOD locus (on mouse chromosome 17) was highly associated with overt diabetes (Cheng and Wakeland, personal communication), suggesting a role of MnSOD in the disease process of this animal model. This preliminary observation of the MnSOD locus being associated with overt diabetes and not insulitis supports our hypothesis that beta cells may be susceptible to IL-1 cytotoxicity due to insufficient radical scavenger potential (Mandrup-Poulsen et 
al. 1990). To our knowledge, the possible existence of genetic variation within the MnSOD locus of the (NOD) mouse has not been reported.

Recently, structurally polymorphic MnSOD protein variants with altered activities was reported (Borgstahl et al. 1992). Selection for MnSOD variants with reduced activity might be a predisposition for diseases, such as diabetes (Asayama et al. 1986, Oberley et al. 1988), that are associated with oxidative damage. This would be in line with the recent observation that mutation in the $\mathrm{Cu} / \mathrm{ZnSOD}$ is associated with amyotrophic lateral sclerosis (Rosen et al. 1993). Finally, mitochondrial damage has been implicated in a rare form of insulin-requiring diabetes (Ballinger et al. 1992), SOD is protective of healthy pancreatic islet tissue transplanted into diabetic animals (Nomikos et al. 1989) and a possible role of SOD in the process of diabetic retinopathy development has been suggested (Kernell et al. 1992).

If genetic variation results in MnSOD variants with reduced activities (Borgstahl et al. 1992), the MnSOD locus may still be a candidate gene for IDDM susceptibility. Whether the RFLPs reported in this study reflects differences in gene expression level, protein level and/or specific activity of the protein is yet to be studied.

\section{REFERENCES}

Andersen, H.U., Jørgensen, K.H., Egeberg, J., Mandrup-Poulsen, T., Nerup, J. (1993). Nicotinamide protects against interleukin-1 $\beta$-induced inhibition of insulin release and production of nitric oxide in rat islets of Langerhans. Diabetologia 36 (suppl. 1), A62.

Asayama, K., Kooy, N.W., Burr, I.M. (1986). Effects of vitamin E deficiency on insulin secretory reserve and free radical scavenging systems in islets. J. Lab. Clin. Med., 107, 459-464.

Ballinger, S.W., Shoffner, J.M., Hedaya, E.V., Trounce, I., Polak, M.A., Koontz, D.A., Wallace, D.C. (1989). Maternally transmitted diabetes and deafness associated with a $10.4 \mathrm{~kb}$ mitochondrial DNA deletion. Nature Genet. 1, 11-17.

Beckman, J.S., Beckman, T.W., Chen, J., Marshall, P.A., Freeman, B.A. (1990). Apparent hydroxyl radical production by peroxynitrite: Implications for endothelial injury from nitric oxide and superoxide. Proc. Natl. Acad. Sci. USA, 87, 1620-1624.

Bendtzen, K., Mandrup-Poulsen, T., Nerup, J., Nielsen, J.H., Dinarello, C.A., Svenson, M. (1986). Cytotoxicity of human pI 7 interleukin-1 for pancreatic islets of Langerhans. Science, 232, 1545-1547.

Borg, L.A.H., Cagliero, E., Sandler, S., Welsh, N., Eizirik, D.L. (1992). Interleukin-1 $\beta$ increases the activity of superoxide dismutase in rat pancreatic islets. Endocrinology, 130, 2851-2857.

Borgstahl, G.E.O., Parge, H.E., Hickey, M.J., Beyer, W.F. Jr., Hallewell, R.A., Tainer, J.A. (1992). The structure of human mitochondrial Mn superoxide dismutase reveals a novel tetrameric interface of two 4-helix bundles. Cell, 71, 107-118.

Busse, R., Mülsch, A. (1990). Induction of nitric oxide synthase by cytokines in vascular smooth muscle cells. FEBS Lett., 275, 87-90.

Cuartero, B.G, Hougaard, D., Pociot, F., Nerup, J., Larsson, L.I. (1992). B-cell cytotoxicity studied by non-radioactive in situ hybridization - a feasibility study. Diabetologia, 35 (suppl. 1), A211.

Hanenberg, H., Kolb-Bachofen, V., Kantwerk-Funke, G., Kolb, H. (1989). Macrophage infiltration precedes and is a prerequisite for lymphocytic insulitis in pancreatic islets of prediabetic BB rats. Diabetologia, 32, 126-134.

Helqvist, S., Bouchelouche, P.N., Johannesen, J., Nerup, J. (1990). Interleukin 1b increases the cytosolic free sodium concentration in isolated rat islets of Langerhans. J. Scand. Immunol., 32, $53-58$. 
Karlsen, A.E., Boel, E., Cuartero, B., Tobiasen, C., Andersen, H.U., Nerup, J. (1993). Cloning of a novel IL-1 inducible nitric oxide synthase (NOS) isoform from rat islets of Langerhans. Autoimmunity, 15 (suppl.), 85.

Kernell, A., Lundh, B.L., Marklund, S.L., Skoog, K-O, Björkstén, B. (1992). Superoxide dismutase in the anterior chamber and the vitreous of diabetic patients. Invest. Ophthalmol. Vis. Sci., 33, 3131-3135.

Klempner, M.S., Dinarello, C.A., Henderson, W.R., Gallin, J.I. (1979). Stimulation of neutrophil oxygen-dependent metabolism by human leukocytic pyrogen. J. Clin. Invest., 64, 996-1002.

Malaisse, W.J., Malaisse-Lagae, F., Sener, A., Pipelers, D.G. (1982). Determinants of the selective toxicity of alloxan to the pancreatic B cell. Proc. Natl. Acad. Sci. USA, 79, 927-930.

Mandrup-Poulsen, T., Bentzen, K., Nerup, J., Dinarello, C.A., Svenson, M., Nielsen, J.H. (1986). Affinity-purified human interleukin 1 is cytotoxic to isolated islets of Langerhans. Diabetologia, 29, 63-67.

Mandrup-Poulsen, T., Helqvist, S., Wogensen, LD., Mølvig, J., Pociot, F., Johannesen, J., Nerup, J. (1990). Cytokines and free radicals as effector molecules in the destruction of the pancreatic b-cells. Curr. top. Microbiol. Immunol., 164, 169-193.

Masuda, A., Longo, D.L., Kobayashi, Y., Appella, E., Oppenheim, J.J. Matushima, K. (1988). Induction of mitochondrial manganese superoxide dismutase by interleukin 1. FASEB J., 2 , 3087-3091.

Matsubara, T., and Ziff, M. (1986). Increased superoxide anion release from human endothelial cells in response to cytokines. J. Immunol., 137, 3295-3298.

Mattiuz, P.L., Ihde, D., Piazza, A., Ceppellini, R., Bodmer W.F. (1970). New approaches to the population genetic and segregation analysis of the HL-A system. In: Terazaki P.I. (ed) Histocompatibility Testing. Copenhagen: Munksgaard, 193-205.

Nath, N., Chari, S.N., Rathi. A.B. (1984). Superoxide dismutase in diabetic polymorphonuclear leukocytes. Diabetes, 33, 586-589.

Nerup, J., Mandrup-Poulsen, T., Mølvig, J., Helqvist, S., Wogensen, L., Egeberg, J. (1988). Mechanisms of pancreatic b-cell destruction in Type I diabetes. Diabetes Care, 11 (suppl.1)], $16-23$.

Nomikos, I.N., Wang, Y., Lafferty, K.J. (1989). Involvement of $\mathrm{O}_{2}$ radicals in 'autoimmune' diabetes. Immunol. Cell. Biol., 67, 85-87.

Nussler, A.K., Di Silvio, M., Billiar, T.R., Hoffman, R.A., Geller, D.A., Selby, R., Madariaga, J., Simmons, R.L. (1992). Stimulation of the nitric oxide synthase pathway in human hepatocytes by cytokines and endotoxin. J. Exp. Med., 176, 261-64.

O'Reilly, L.A., Hutchings, P.R., Crocker, P.R., Simpson, E., Lund, T., Kioussis, D., Takei, F., Baird, J., Cooke, A. (1991). Characterization of pancreatic islet cell infiltrates in NOD mice: effect of cell transfer and transgene expression. Eur. J. Immunol., 21, 1171-80.

Oberley, L.W. (1988). Free radicals and diabetes. Free Radic. Biol. Med,. 5, 113-124.

Pociot, F., Mølvig, J., Wogensen, L., Milner, C.M., Campbel, R.D., Nerup, J. (1990). Insulin dependent diabetes - a polygenic disease? Implications of tumor necrosis factor $b$ and heat shock protein 73 polymorphisms. Diabetologia, $\mathbf{3 3}$ (suppl), A38.

Pociot, F., Mølvig, J., Wogensen, L., Worsaae, H., Nerup J. (1992). A TaqI polymorphism in the human interleukin-1b (IL-1b) gene correlates with IL-1ß secretion in vitro. Eur. J. Clin. Invest., 22, 396-402.

Pociot, F., Briant, L., Jongeneel, C.V., Worsaae, H., Mølvig, J., Abbal, M., Thomsen, M., Nerup, J., Cambon-Thomsen, A. (1993a). Association of tumor necrosis factor (TNF) and class II MHC alleles with the secretion of TNFa and TNFb by human mononuclear cells: A possible link to insulin-dependent diabetes mellitus. Eur. J. Immunol., 23, 224-231.

Pociot, F., Johannesen, J., Rønningen, K.S., Lorenzen, T., Nerup, J., The Danish study group of diabetes in childhood (1993b). Comparison of genetic susceptibility factors in familial index cases and "true sporadic" cases Autoimmunity, 15 (suppl.), 36. 
Rosen, D.R., Siddique, T., Patterson, D., Figlewics, D.A., Sapp, P., Hentati, A., Donaldson, D., Goto, J., O’Regan, J.P., Deng, H-X., Rahmani, Z., Krizus, A., McKenna-Yasek, D., Cayabyab, A., Gaston, S.M., Berger, R., Tanzi, R.E., Halperin, J.J., Herzfeldt B., Van den Bergh, R., Hung, W-Y, Bird, T., Deng, G., Mulder, D.W., Smyth, C., Laing, N.G., Soriano, E., Pericak-Vance, M.A., Haines, J., Rouleau, G.A., Gusella, J.S., Horvitz, H.R., Brown, H. jr. (1993). Mutations in $\mathrm{Cu} / \mathrm{Zn}$ superoxide dismutase gene are associated with familial amyotrophic lateral sclerosis. Nature, 362, 59-62.

Sandler, S., Andersson, A., Hellerström, C. (1987). Inhibitory effects of interleukin 1 on insulin secretion, insulin biosynthesis, and oxidative metabolism of isolated rat pancreatic islets. Endocrinology, 121, 1424-1431.

Sandler, S., Bendtzen, K., Borg, L.A.H., Eizirik, D.L., Strandell, E., Welsh, N. (1989). Studies on the mechanisms causing inhibition of insulin secretion in rat pancreatic islets exposed to human interleukin- $1 \beta$ indicate a perturbation in the mitochondrial function. Endocrinology, 124, 1492-1501.

Simchowitz, L. (1985). Intracellular $\mathrm{pH}$ modulates the generation of superoxide radicals by human neutrophils. J. Clin. Invest. 76, 1079-1089.

Southern, C., Schulster, D., and Green, I.C. (1990). Inhibition of insulin secretion by interleukin$1 \beta$ and tumour necrosis factor- $\alpha$ via an arginine-dependent nitric oxide generating mechanism. FEBS Lett., 276, 42-44.

Spielman, R.S., Baur, M.P., Clerget-Darpoux, F. (1989). Genetic analysis of IDDM: Summary of GAW5 IDDM results. Genet. Epidemiol., 6, 43-58.

Stadler, J., Stefanovic-Racic M., Billiar, T.R., Curran, R.D., McIntyre, L.A., Georgescu, H.I., Simmons, R.L., Evans, C.H. (1991). Articular chondrocytes synthesize nitric oxide in response to cytokines and lipopolysaccharide. J. Immonol., 147, 3915-20.

Vorbij, H.A.M., Jeucken, P.H.M., Kabel, P.J., de Haan, M,, Drexhage, H.A. (1989). Dendritic cells and scavenger macrophages in pancreatic islets of prediabetic BB rats. Diabetes, $\mathbf{3 8}, 1623$ 1629.

Welsh, N., Eizirik, D.L., Bendtzen, K., Sandler, S. (1991). Interleukin-1 $\beta$-induced nitric oxide production in isolated rat pancreas islets requires gene transcription and may lead to inhibition of the Krebs cycle enzyme aconitase. Endocrinology, 129, 3167-3173.

Wong, G.H.W., Goeddel, D.V. (1988). Induction of manganous superoxide dismutase by tumor necrosis factor: Possible protective mechanism. Science, 242, 941-944.

Xiang, K., Cox, N.J., Hallewell, R.A., Bell, G.I. (1987). Multiple TaqI RFLPs at the human manganese superoxide dismutase (SOD2) locus on chromosome 6. Nucleic Acids Res.,15, 7654. 


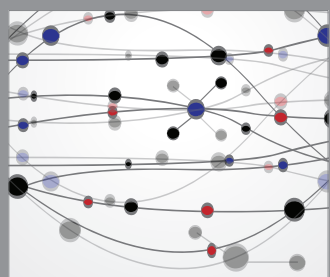

The Scientific World Journal
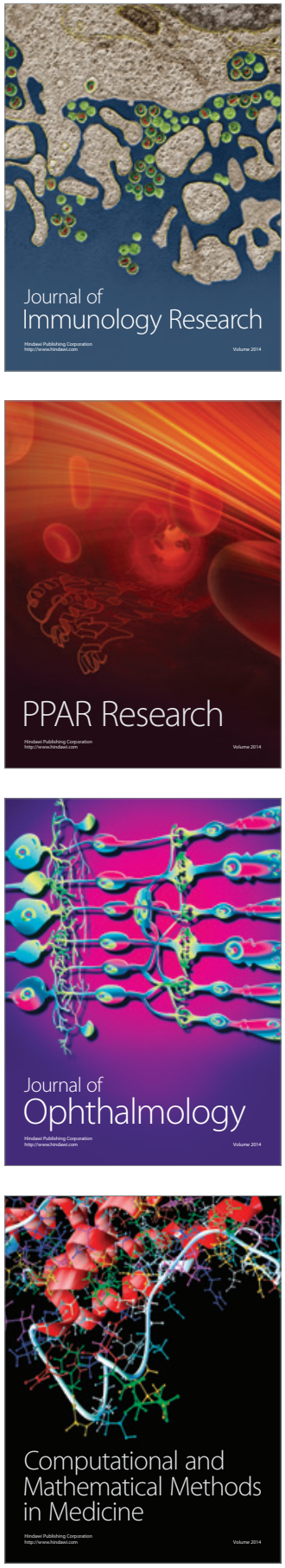

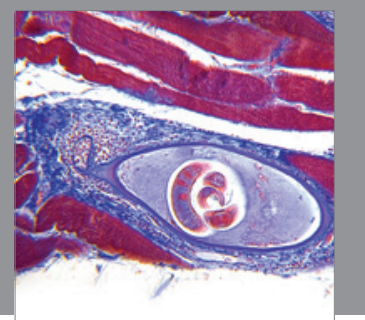

Gastroenterology

Research and Practice
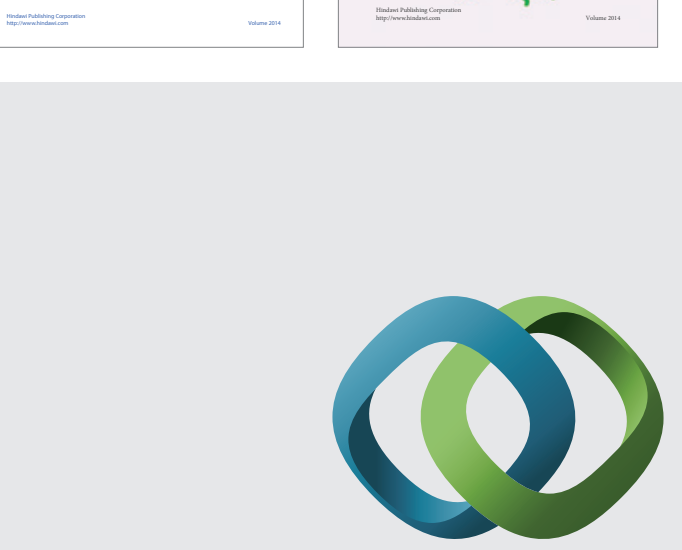

\section{Hindawi}

Submit your manuscripts at

http://www.hindawi.com
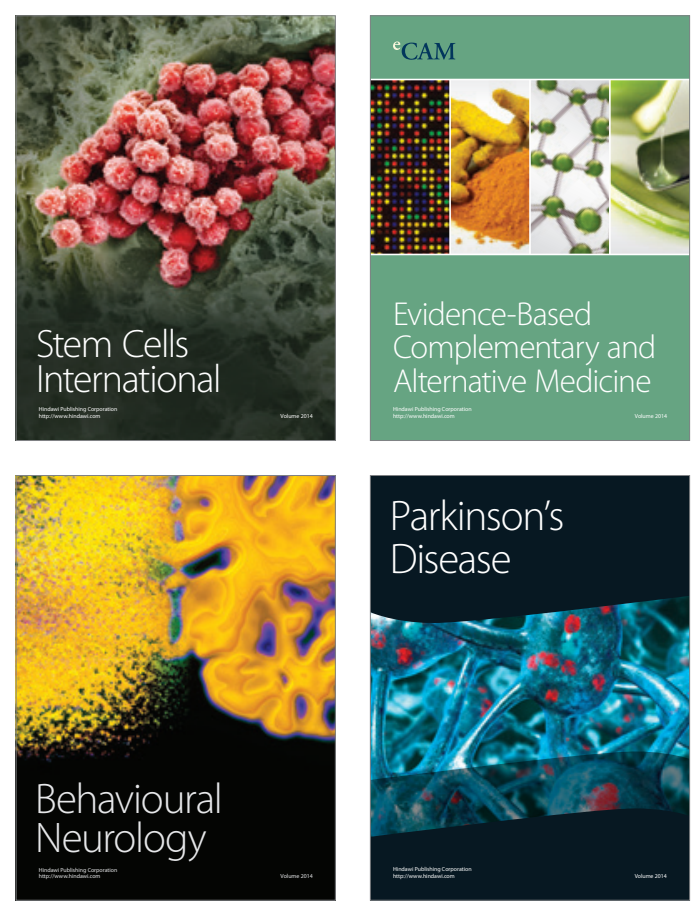

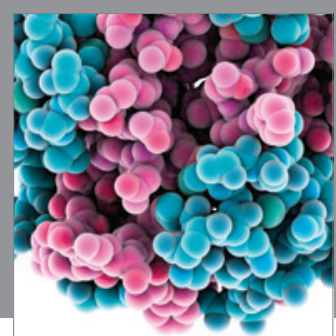

Journal of
Diabetes Research

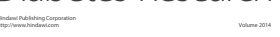

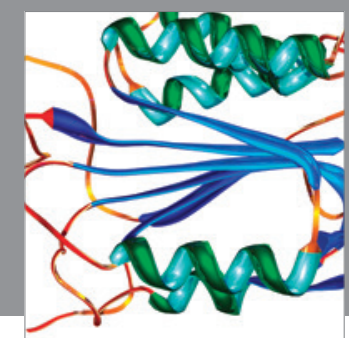

Disease Markers
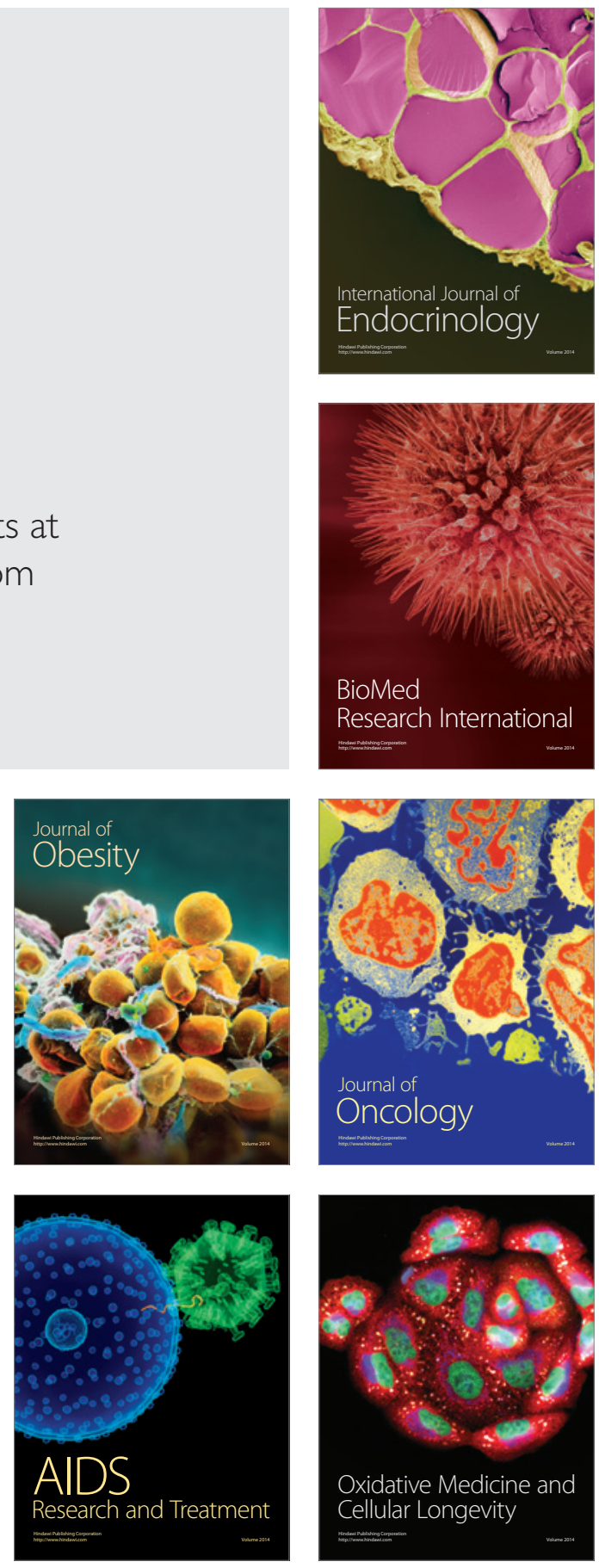